Article

\title{
"The Very Highest Level of Mythic Resonance." Angela Carter and the Trope of Recognition
}

\author{
Dominika Oramus \\ Institute of English Studies, University of Warsaw, 00-681 Warsaw, Poland; dominika.oramus@uw.edu.pl \\ Received: 19 June 2020; Accepted: 10 July 2020; Published: 16 July 2020 \\ check for \\ updates
}

\begin{abstract}
This essay aims at adding to the critical debate on Angela Carter and myths from a more technical perspective and discusses her keen interest in the "lo and behold" moment of recognition. I claim that for Carter myths "work" in literary texts by producing a sudden illumination. At that moment, an image reveals itself to be interposed from an older story that has, or used to have, some cultural importance. In order to describe this phenomenon, I am going to refer to Aristotle's definition of recognition in his Poetics and essays of C.G. Jung, for whom myths are instances of revelation. To prove that Carter was very much interested in the technicalities of recognition, I analyse her non-fiction devoted to Edgar Allan Poe and Charlotte Brontë. Carter's sample mythic reading of Jane Eyre (1847) and her plans to re-write the last chapter of this novel provide me with enough material to risk a hypothesis regarding how, in her opinion, myths might intertextually enrich the reading experience.
\end{abstract}

Keywords: Angela Carter; recognition; C.G. Jung; myth; image

In her ideological and artistic manifesto, "Notes from the Front Line", Angela Carter describes her own writing as a "demythologizing business" (Carter 1997, p. 38), which implies that both her fiction and non-fiction are executed with a consciously crafted agenda and are, essentially, anti-mythic. This succinct phrase has become the critical latchkey to Carter's oeuvre, repeated and elaborated on in the Interview Carter gave to Anna Katsavos (1994), and, ever since, Carter's attitude to myths has become the subject of numerous papers, articles and book-long dissertations devoted to her works (Bryant 1989; Gustar 2004; Pérez-Gil 2007; Mattson and Tatar 2016). Asked how she understood the term "myth", Carter agreed with Roland Barthes that myths are ideas, images and stories which we trust without thinking about what they mean, where they come from, or what social purposes they serve. Barthes derived such myths from the past (Barthes 1993, p. 11) as history stylized to look like nature and given to us to believe. Demythologizing shows how this is done, and the culturally determined "nature" of women is among the most important topics undergoing this procedure. Thus, Carterian scholars (Dimovitz 2016, p. 57; Gamble 2006, p. 145) write about Carter demythologizing female sexuality and gender relations or Carter exposing the fictions that surround womanhood. Carter believes that myths are "the social fictions that regulate our lives" and they all "are products of the human mind and reflect only aspects of material human practice" (Carter 1997, p. 38). In "Notes from the Front Line", she claims she is interested in myths "just because they are extraordinary lies designed to make people unfree" (Carter 1997, p. 38). For her, just like for the theologian Rudolf Bultmann and the philosopher Hans Jonas, myths describe "not the external world but the human experience of that world" (Segal 1999, p. 81). Moreover, her own use of mythology "ostensibly functions as a subversion of those religious beliefs that would restrict human freedom" (Dimovitz 2016, p. 5). Her concept of myth as a way of thinking derived from the past is indebted to such theorist as Lucien Lévy-Bruhl, Ernst Cassirer, and Henri Frankfort. In An Essay on Man: An Introduction to a Philosophy of Human Culture, Cassirer discusses the first mythological explanations of the universe and finds there "a 
primitive anthropology side by side with a primitive cosmology," (Cassirer 1992, p. 8). He claims that myths evolved from primitive times to prepare the way for the rise of modern culture. Intellectually, such an idea is at Carter's starting point.

In this essay I add to the critical debate on Angela Carter and myths from a more technical perspective and discuss her keen interest in the "lo and behold" (Carter 1997, p. 482) moment of recognition. I claim that, for Carter, myths "work" in literary texts by producing a sudden illumination. At that moment, an image reveals itself to be interposed from an older story that has, or used to have, some cultural importance. In order to describe this phenomenon, I refer to Aristotle's definition of recognition in his Poetics and essays of C.G. Jung, for whom myths are instances of revelation. To prove that Carter was very much interested in the technicalities of recognition, I analyse her non-fiction devoted to Edgar Allan Poe and Charlotte Brontë. Carter's sample mythic reading of Jane Eyre (1847) and her plans to re-write the last chapter of this novel provide me with enough material to risk a hypothesis regarding how, in her opinion, myths might intertextually enrich the reading experience. Carter's article about Eric Rhode's On Birth and Madness (1987) — together with references to her own fiction, where she ridicules the abusive practice of re-mythologizing (i.e., the crafting of new myths for ideological aims) - give inglorious examples of how not to use the trope of recognition in literary texts.

First and foremost, for Angela Carter, the smallest unit of a myth is an image, and the question why some images resonate with "something" within the human mind is puzzling. By splitting myths into increasingly smaller units, one may finally identify a kernel-the smallest particle endowed with the power to bring about illumination. This illumination, almost like James Joyce's epiphany or Andre Breton's surrealist practice of discovering, happens to the reader: Carter believes that people react to certain images because of their previous experience and their cultural competence. Its mechanism is elusive, yet the Aristotelian notion of recognition (anagnorisis) might be useful. For Carter, the reader recognizes the mythic provenience of a seemingly mundane image in the moment of illumination.

In Part XI of Poetics, Aristotle defines anagnorisis as a discovery, a change from ignorance to knowledge:

The best form of recognition is coincident with a Reversal of Intention, as in the Oedipus ... but the recognition which is most intimately connected with the plot and action is, as we have said, the recognition of persons. This recognition, combined with Reversal, will produce either pity or fear; and actions producing these effects are those which, by our definition, Tragedy represents. (Aristotle 1902, p. 41)

Aristotle writes about "persons" - characters in literary texts-who discover a truth about their own identity (or the identity of other characters) which results in a change in their fortune: new knowledge prompts them to change their lives. Though not as popular as mimesis or diegesis, the notion of anagnorisis is often applied to discuss both classics and contemporary culture. Terence Cave in Recognitions: A Study in Poetics (Cave [1988] 2011) famously describes the uses of recognition in French and English literature. From the Renaissance to Joseph Conrad, anagnorisis is a recurrent literary trope and, thanks to psychoanalysis, its meaning in contemporary culture has shifted: characters recognize a hidden truth about themselves. Applying this notion to the works of Angela Carter-the writer who is suspicious of depth and keen on surfaces, who is more interested in looking than in analysing-may seem far-fetched. In Nothing Sacred, she describes her stay in Japan, saying that "I started trying to understand things by simply looking at them very, very carefully" (Carter 1992, p. 28) and this approach seems to characterize all her work. Carterian scholars (Sage 1994, pp. 8-11; Dimovitz 2016, pp. 84-102) emphasize her fascination with looking, mirrors and mirror images. Yet for Carter, anagnorisis is focused not on Aristotelian "persons" but on the image; by the sudden realization that the image we see is in fact interposed from some story we already know, we are prompted to look at the characters in a new way. It is not their fate that changes but our perception of their story. Consequently, for the myth to resonate, readers must share mythic associations as a result of having been brought up within the same culture, say, in the contemporary West. 
Therefore, technically speaking, myths come from the past; we inherit them, or we are born into a culture which imposes them on us and tells us who we are. Heather L. Johnson, in "Unexpected Geometries: Transgressive Symbolism and the Transsexual Subject in Angela Carter's The Passion of New Eve" (1997), suggests Carter's indebtedness to Jung in her disclosure of the relation between the metaphorical and the literal in "the living metaphor" (Bristow and Broughton 1997, p. 169). Johnson quotes Jung's Psychology and Alchemy (1980), in which he describes symbols as oxymorons "neither abstract nor concrete, neither rational nor irrational, neither real nor unreal. It is always both" (Bristow and Broughton 1997, p. 169). Certainly, Jungian discussion of "archaic remnants" of prehistoric and unconscious development in the human psyche, which he calls "archetypes" or "primordial images" (Jung 1978, p. 57), is one of Carter's intertexts. Though many critics find the notion of the collective unconscious seriously flawed-which Andrew Neher shows in "Jung's Theory of Archetypes: A Critique" (Neher 1996), and even Carter herself once called him "that idiot Jung"- -her journals prove that throughout her life she read extensively into his texts (Dimovitz 2016, p. 20). Jung famously states that

The archetype is a tendency to form such representations of a motif-representations that can vary a great deal in detail without losing their basic pattern ... What we properly call instincts are physiological urges, and are perceived by the senses. But at the same time they also manifest themselves in fantasies and often reveal their presence only by symbolic images. These manifestations are what I call the archetypes. (Jung 1978, p. 58)

He postulates that similarities between the motifs of fairy tales, folklore and myths are evidence of this universality. Robert A. Segal, in Theorizing about Myth (1999), notices that once Jung establishes the uniformity of psychic events in time and space, using myths as his evidence, he goes on to refute Freud's account of such universality. Myths do not invoke one's past or things forgotten or repressed an individual; they are the product of the collective unconscious. Myths are not about gods or the physical world but about the human mind: "in fact, the whole of mythology could be taken as a sort of projection of the collective unconscious ... Just like constellations were projected into heavens, similar figures were projected into legends and fairy tales or upon historical persons" (Jung 1969, p. 69).

Both Aristotle's theory of anagnorisis and Jung's psychoanalysis shed some light on how myths work by revelation and how, upon recognizing mythic motifs in a literary text, the reader's perspective shifts. Angela Carter is keenly interested in this sudden shift and in the way it generates new meanings. The references to the Oedipus myth are for her the most prominent: "If you look at the portrait one way up, it looks like this; and if you turn it upside down, lo and behold! The elements of representation turn themselves into a quite different representation" (Carter 1997, p. 482), she writes in "Through a Text Backwards: The Resurrection of the House of Usher" (first published in Metaphors in January 1987, reprinted in Shaking a Leg. Collected Journalism and Writings). In this article, devoted to Edgar Allan Poe, she claims that his Gothic stories prompt the reader to look frantically for the right perspective in order "to find out what is really going on" (Carter 1997, p. 482, italics in the original). Poe's theatricality, his picturesque landscapes, his "cardboard" scenery appear to be that of conventional horror, and yet we feel there is something more to it; we have the haunting feeling of a strange familiarity, as if of a half-forgotten dream: "We feel we have been here before" (Carter 1997, p. 482). What we recognize is the echo of the Oedipus myth. Carter compares this sensation to a déjà vu, which leads her to Sigmund Freud's The Interpretation of Dreams (1899) and his thesis that the feeling of familiarity "means that we are remembering the bodies of our mother" (Carter 1997, p. 482), and his claim that in dreams (myths, stories) mothers' wombs are symbolized by houses. Finding the latter ridiculous, Carter goes on to explain that if Poe's mother's body is a haunted house it is "one haunted by allusion" (Carter 1997, p. 482) to other texts, mostly dramas (his mother was a strolling actress). Instead of psychoanalyzing Poe in search of some mysterious "depth," she advises reading the text "backwards" and look at the surface made of literary allusions from a shifted, un-conventional perspective. She playfully applies Freudian notions of the patent and the latent content of a dream (a myth, a story) to her reading of Poe 
and reverses them in her attempt to turn "The Fall of the House of Usher" (1839) upside down, as in the case of the picture she mentions, whose elements of representation turn themselves into a different representation prompting recognition-anagnorisis.

Carter's critical strategy in "Through a Text Backwards: The Resurrection of the House of Usher" gives some important clues to her understanding of myths and literature. In this piece of literary criticism, she associates the moments of shifting perspective with the haunting feeling of intertextual recognition. This, in turn, leads her to refer to psychoanalysis, recalling Freudian terms, and laughing at the way Freud provides them as a key to the lost infant experience. Then she redefines his terms and uses them to her own ends, at the same time acknowledging that psychoanalysis might be useful. She, just like Jung, disagrees with Freud's claim that our very early half-lost experience shapes our unconscious, and later in life, we try to recover the experience by anamnesis, i.e., by recognizing in images from dreams, myths or stories traces of those lost memories and recovering them. Therefore, in her opinion, whatever mythic images resonate with, it is not the unconscious, at least not the unconscious as defined by Freud. Anagnorisis is not anamnesis. For all her fondness for the language of psychoanalysis, which serves as a handy set of metaphors, Carter criticizes the claim of the universality of Freudian theories. Jung's thesis that we do share a collective unconscious is for her more accurate, but she does not agree that what we share is inborn and natural (and thus universally human). During moments of recognition, we are made aware of intertexts our culture holds so important that they are erroneously given quasi-holy status. "[H]ow deeply psychoanalysis is concerned with culture. Not only broadly, with culture as opposed to nature, but also in its narrowest sense-that is high-bourgeois culture" (Carter 1997, p. 74), she exclaims, "infuriated" (Carter 1997, p. 74) by the way pure cultural products are passed on as universal truths.

Significantly, Carter 'the reader' is both suspicious of myths and fascinated by their power to stir our psyche. It is the previously mentioned definition of myth proposed by Roland Barthes that helps us understand her attitude. Yet, in Carter's non-fiction, the term "myth" is in itself mythic, it is derived from history, handed down to us and overlaid with earlier meanings. From the standard definition of myth as "an outdated and incorrect explanation of the world" (Segal 1999, p. 19) to discussions of the term in texts by Mircea Eliade and Carl Gustav Jung, theorizing about myth is an important context for understanding Carter's literary criticism. Eliade's (1968) belief that myths "narrate ... all the primordial events in consequence of which man became what he is today-mortal, sexed, organized in a society, obliged to work in order to live, and working in accordance with certain rules" (Eliade 1968, p. 11), is for her false but important for deconstructing the alleged bond between nature and history. Carter looks for mythic intertexts in the novels she reads even though her main strategy in reading fiction is to see every text as "a cultural product, with the specific conditions of time and place of its composition mediating its universality" (Carter 1997, p. 73). Her Introduction to the Virago edition of Charlotte Brontë's Jane Eyre (1990, reprinted in Expletives Deleted: Selected Writings) is a prime example of such a method; she places the novel in its cultural, social and historical context but looks for images charged with a mythic resonance that provokes anagnorisis.

From the point of view of social history, Brontë's protagonist is, according to Carter, a woman of her own who could only have lived in the rapidly changing Britain of the mid-19th century, when there were not yet guidelines for the behaviour of middle-class, educated girls capable of supporting themselves and not dependant on family connections. Jane Eyre has the respectable profession of a teacher. Carter suggests that the profession of a writer would have been even more convenient, but Brontë did not want the book to be received as a disguised autobiography. All the same, Brontë's biography is for Carter an important intertext; she emphasises that Brontë lived in a post-romantic, industrial Britain and in her girlhood fantasised about the realm of Angria, which she and her brother described in their juvenile stories and which they nostalgically peopled with romantic heroes. Jane Eyre, as Carter interprets it, is indebted to these fantasies. When Jane sees Rochester for the first time, because of the scenery and the direction of her gaze, he seems similar to the Duke of Zamorna, "a Byronic homme fatal ... without a touch of irony" (Carter 2012) from Angrian stories. The image 
evokes nostalgia, romanticism and the Gothic, yet the narrative itself is concerned with an issue that pertains to social history. Significantly, she notices Brontë's lack of ironic distance to her passionate characters; the novel is serious-the passions should not be laughed at. In Carter's opinion, Brontë seeks "to perform an analysis of the operation of erotic attraction upon a young woman who is not rich nor beautiful but, all the same, due to her background and education, free to choose what she does in her life." (Carter 2012). Jane turns down Rochester's tempting offer to live with him in the South of France for very level-headed reasons (Carter 2012), and marries him only when he "loses the shaggy grandeur with which the unfulfilled desire has dowered him" (Carter 2012), and "becomes ... something else. A husband" (Carter 2012).

Yet, having discussed the specifics of the time and place that the novel was written in, Carter directs the reader's attention to one specific image that provokes anagnorisis, thereby demonstrating how Brontë inscribes the story of Jane into the mythic paradigm we already know. Carter does not say much about the final chapter of the novel, where the main storyline and the subsidiary plots are brought to a close; instead, she concentrates on the last scene of the penultimate chapter. Apparently, it simply prepares the ground for the happy ending: the lovers are reunited, and Jane learns what happened at Thornfield during her absence. She realizes that Rochester is no longer "a Byronic homme fatal" and consents to marry him. At the end of the chapter we see both of them slowly walking in the direction of the house:

After Rochester has been blinded and maimed, we are left with the image of himself and Jane, a grizzled, ageing, blind man, led by the hand by a young girl (Jane is young enough to be his daughter). Suddenly astonishingly they look like Oedipus and Antigone, having ascended to the very highest level of mythic resonance. (Carter 2012)

Unexpectedly, and for a fraction of a second, Jane seems to resemble Antigone and Rochester-an old Oedipus aware of his sins and helped along by his strong-willed, virtuous daughter, which adds a new angle to the story. Just as in the case of Carter's reading of Edgar Allan Poe's tales, she points to the "lo and behold!" moment in which "the elements of representation turn themselves into a quite different representation." This anagnorisis makes the image of the ill-matched lovers resonate unexpectedly and brings about her reference to Oedipus the King. Seeing Rochester as a broken-down father makes Carter sensitive to the question of paternity in the novel. This is quite opposite to Gilbert and Gubar who, in their seminal essay "A Dialogue of Self and Soul: Plain Jane's Progress" (Gilbert and Gubar 1984), focus on the mother figures Jane meets on her way, from Mrs Reed to Mary and Diana Rivers. Carter does not suggest that Jane Eyre is a re-writing of Oedipus the King nor that Jane is a female Oedipus subliminally attracted to her father, whom she does not recognize. She withdraws from interpreting the mythic resonance, yet she spots this disturbing image and notices how it enriches the reading of Jane Eyre by bringing about a whole set of issues: paternity and maternity, incest, female sexuality and why the question "Who is my mother?" seems less important than "Who is my father?"

Carter's Introduction to Jane Eyre might be intertextually linked to a number of texts inspired by Brontë from the previously mentioned essay by Sandra Gilbert and Susan Gubar in the Mad Woman in the Attic volume, to Frances Tower's Tea with Mr Rochester (1949), to Jean Rhys's Wide Sargasso Sea (1966), to Lorna Sage's reading of the latter novel in Women in the House of Fiction (1992), to numerous film adaptations of this classic and to James Fordee's humorous The Eyre Affair (2001). Gilbert and Gubar explore the silenced and repressed voices in the novel, Dominica-born Rhys adopts the perspective of the colonies and re-writes the story from the point of view of Bertha Rochester and, as Lorna Sage inquisitively notices, also adds the perspective of young Rochester displaced in the Caribbean. Tower (whose story Carter included in her Wayward Girls and Wicked Women (1986) collection, so she knew her and read her) and Fordee concentrate on how Brontë's novel fascinates readers born in diverse times and places, making them re-read the novel and indulge in the Barthesian pleasure of the text. Juxtaposed with these fictions and non-fictions, Carter's reading of the novel strikes us as more methodical. Carter examines the text, identifies the Oedipus and Antigone image with the 
"mythic resonance" to it and juxtaposes it with two enigmas. Firstly, there is the question of whether Rochester is the father of Adèle, his charge whom he brought from France after her mother-his former mistress-died. Rochester persistently denies paternity, and Jane persistently tries to find in Adèle some traces of similarity to him. Secondly, why, in the last chapter of Brontë's novel, does Rochester recover his eyesight before fathering Jane's children, which, in Carter's opinion, is a hasty attempt to remove his uncanny resemblance to Oedipus so that the conventional "happy ending" may take place.

The Virago Introduction does not seek to answer these questions. Carter points to the ambiguities brought about by the act of recognition and then stops short, withdrawing from offering any serious in-depth analysis of Jane's alleged latent bias. Myths enrich the reading experience and invite the reader to participate in the storytelling. If Carter was to enter any intertextual game with the mythic resonance of Brontë's novel, it would be as a writer, not as a critic, and with humour rather than self-assurance.

Perhaps, then, it is not surprising that, after Carter's untimely death, it turned out that her last literary project was intricately connected to Jane Eyre. Edmund Gordon, in The Invention of Angela Carter: A Biography (2016), gives a summary of Adela, the novel Carter was planning to write but managed only to pen down the synopsis that was found in her papers. It is a fantasy about what happened to Adèle after the penultimate chapter of Jane Eyre, partly a "sequel", partly a rewriting of the final chapter of Jane Eyre. In Brontë's novel, in this final chapter, Jane very briefly summarises 10 years of her married life: mentions how she rescues Adèle from a boarding school, tries to teach her at home, and finds her a better school where they make the girl "English" and uproot her French ways. Reread against Jean Rhys's Wide Sargasso Sea-partly a prequel to Jane Eyre, partly a rewriting of the Thornfield part of the novel—-the last chapter implies that the French-turned-English Adèle (Adela) and the Caribbean-turned-English Antoinette (Bertha) are uncanny doubles and their symmetrical lives revolve round the same axis: the Jane-Rochester union. Judging from the synopsis, Carter's Adela was to ironically reverse Rhys's narrative of Bertha's gradual loss of identity; in Carter's rewriting, Adèle learns from her French teacher at school that her biological mother is not dead but lives in Paris and has joined the revolutionary movement. Adèle leaves the school for Paris, but on her way, she visits Thornfield and has sex with Rochester, who, as she then learns, is her father. In France, Adèle finds her mother (Gordon 2016, p. 404). Finally, both women are arrested for a political offence. It is Jane who rescues Adèle from a Parisian prison and tells her that Rochester has, at last, acknowledged her as his daughter. At the end, Adèle decides that she would rather be known as her mother's daughter (Gordon 2016, p. 404).

In the synopsis, Carter emphasises that Adela was to be a funny novel "with laughs" (Gordon 2016, p. 404) and ironical distance. Probably, Adela would have resolved the two enigmas mentioned in Carter's Introduction to Jane Eyre by playing with the reader's recognition of the female Oedipus motif. Unhappily enough, there is no way of saying how the recognition would have worked in the novel nor what voice Carter would have given to Adèle. Discussing a novel that has not been written is, of course, impossible, as is guessing why Carter chose Jane Eyre as her intertextual springboard. Yet, juxtaposing the synopsis with the above-discussed Introduction to Brontë's novel allows some insights.

The "mythic resonance" of the image at the end of Jane Eyre is, for Carter, an example of how, thanks to recognition, a classic text may generate new meanings. Myths "open" literary works if we are playful and do not try to deliver a final, profound interpretation of the characters or claim that recognition of myth proves something about universal human nature. Carter is critical of books in which references to myths are abused and recognition is a tool of manipulation. The blind belief that myths are universal and a key to our unconscious "infuriates" her in Eric Rhode's On Birth and Madness, a non-fiction memoir written by a psychiatrist working in a puerperal breakdown unit. Carter reviews the book (the review was originally published in May 1987 in LRB as "Doing It to Mama"), calling it "wayward", "sloppy" and "imprecise". She is outraged by the condescending way women are objectified by male doctors-as if "there aren't any women psychiatrists around" (Carter 1997, p. 74) to ask how it feels to give birth—and, above all, by using Freudian theories as "sacred" writs. Sophocles's Oedipus the King and Freud's reading of the play are given by Rhode as undeniable evidence of what 
human nature is and how men feel about their parents (seemingly devoted to maternity the book is in fact focused on paternity). Carter is precise in describing the erroneous approach to myths and tells us why it is wrong, which might be helpful in understanding how she thinks myths should be approached.

Firstly, she comments on the dependence of myths on flesh, i.e., on a physical difference. Rhode objectifies women as "others" because they can have babies and men cannot- that is why they are men - if they could they "would become magical objects of strangeness, veneration, obloquy, awe, disregard, and oppression, recipients of all the effects of the syndrome of holy terror" (Carter 1997, p. 73). Myth is thus germinated in an attempt to master the fear of the other (and this otherness lies in the properties of the flesh), which is done in Barthesian fashion by translating nature into culture and passing the cultural artefact as nature on to the next generations. Secondly, Rhode is not capable of perceiving what the "universality" of myths means. He does not "think of Oedipus the King as a cultural product, with the specific conditions of time and place of its composition mediating its universality .... He seems to think of the Oedipus family as though they were real people." (Carter 1997, p. 74). Similar to those Shakespearean scholars who seriously attempted to psychoanalyze Hamlet, he disregards the difference between myth as a recurring pattern and the particulars of its realization in a given text written in a given epoch. Thirdly, by making the question "Who is your father?" the very centre of everyone's identity, self-esteem and emotional balance, Rhodes focuses on the moment of human history when property started to be inherited through the male line. Then, he erroneously calls what was true in that particular moment to be universal to human nature.

Having demonstrated the dangers of using myths to support the thesis of the universality of patriarchal culture, Carter does not fall into a trap of offering the "correct" matriarchal explanation of myths, but signals that she is aware of its mirror-like dangers:

One could argue that Oedipus the King is really, deep down, about the overthrow of Mother Right, that the play contains transforms, subverts, patricises the ideology of those antique, matrilineal communities around the Mediterranean celebrated somewhat circumspectly in The Golden Bough, and increasingly cherished by women of my type as we reach a certain age, in which kingship was attained by marriage with the queen and terminated in ritual combat with the inevitable defeat by a nubile successor when the hapless consorts hairline started to recede or his ardour flag. (Carter 1997, p. 75)

Therefore, descending "deep down," the myth (or rather Sophocles' version of it written in specific conditions of time and space) may allow us to arrive at a hidden level where we find yet another myth. In this case, the ur-myth from the days before the question "Who is your father?" becomes much important. For women readers outraged by the myopic ideology behind books such as On Birth and Madness, the reversed myth is much more pleasurable: "I love the poetic truth at the kernel of it" (Carter 1997, p. 75), Carter confesses. And yet she is not going to let the ur-myth seduce her; she knows its sources and is aware that "Graves's anthropology is as shaky as Frazer's" (Carter 1997, p. 75). The matriarchal myth, which one can find in Oedipus the King in an act of a sudden anagnorisis - recognizing that by looking at it upside down we may see a different representation-is not "real", the anthropology is shaky, and the truth is only poetic.

Blinded by myth, Rhode fails to acknowledge how painful the clash of nature and culture epitomized in the act of giving birth might be. He does not really notice women who have just become mothers and cannot cope with it. For him, myths are literally real, mothers are mythic creatures, and he "invests motherhood with an almost occult quality" (Carter 1997, p. 76). Reading Oedipus the King, he focuses on Oedipus, who is everybody, and is not interested in Jocasta, who is at the centre of the myth. He finds it probable that Oedipus failed to recognize his real father in the strange old man he kills at the crossroads but considers it incredulous "that he fails to sense that the bereft queen (whom he marries) might be his mother" (Rhode qtd in Carter 1997, p. 77). Carter mercilessly ridicules his metaphysical faith in "the intra-uterine address" that Oedipus should have recognized during 
intercourse with Jocasta and his implication that some mystical longing for the lost Eden of the womb prompted Oedipus to have sex with her. A much easier explanation is that, like some other young men, he "found older women quite attractive" (Carter 1997, p. 77). Thus, discussing Rhode's misuse of Oedipus the King, Angela Carter points to at least three flaws: his mythologizing the flesh (a female's biological ability to bear babies); his consecutive belief in the universality of myth (all people are biologically the same, so all births and parenthoods send us back to the same set of dependencies); finally, his belief that anagnorisis is the Freudian anamnesis (one should remember the womb of his mother and recognize it mythically).

The clash of the Oedipal myth and the equally false ur-myth of matrilineal communities is depicted by Carter in The Passion of New Eve (1982), in which she very carefully examines both patriarchal and matriarchal clichés associated with this clash. The theories of Frazer and Graves that she mentions in her review of Rhode's books are intertexts she playfully invokes and juxtaposes with references to Freud, and her criticism of the misuse of myths is focused on the aspects she criticizes in the review. In the novel, Mother's sect strives to build a pre-Oedipal womb-like paradise in the underground realm they call (after William Blake) Beulah. "The garden in which Adam was born lies between my thighs" (Carter 1982, p. 63) says Mother, who is herself a "mythological artefact" (Carter 1982, p. 60), a seductress of captured males and a castrating surgeon; her acolytes are feminist priestesses who venerate grain, soil, and vegetation. "NOW YOU ARE IN THE PLACE OF BIRTH" (Carter 1982, p. 52, caps in the original) they greet newcomers. The cult of Mother is a patchwork religion, combining fragments of diverse mythic cults of Goddesses of old. In a litany, she is identified with, among many others, Alphito, Demeter, Ai-uzza great goddess of Arabia Deserta, Queen of the Underworld Emperess of Demons, maze-queen, corn-queen, barley-queen, our lady of the cannibals, Carridwen/Cerridwen, Black Anu the Cannibal, Bellili the willow mother, Arianrhod, Rhiannon, Di-Ana (from Carter 1982, pp. 61-62) and about 20 other mythic-sounding names. These names are interlaced with her attributes: she controls life and death, birth and death, womb and underworld, plants, animals and the cosmos; her cult comes from the days "when men put on false breasts in her honour" (Carter 1982, p. 62). What is implied is some pre-historical past from before patriarchy, a myth which, like the name Beulah itself, is derived from literature, not any "real" civilization. The very end of the litany and the narrator's exclamation at hearing the last of names are telling:

Kali, Maria, Aphrodite

Jocasta.

Jocasta, Jocasta, Jocasta'.

(Jocasta? Why Jocasta?) The gong emitted a final, infinitely echoing clang. (Carter 1982, pp. 62-63)

When patriarchal gods take over in the history of our civilization (as the sect reconstructs it from intertextual sources), Mother is dethroned by Father and takes on a new identity. Becoming Jocasta, she epitomizes the ultimate object of every man's desire: his mother. The sect's sacred ritual is the abolition of the Oedipus myth. The rite starts by a recitation of "Oedipus wanted to live backwards" (Carter 1982, p. 53), and narrates Oedipus's attempts to restore pre-patriarchal order and his failure. The conclusion is "But Mother won't botch the job" (Carter 1982, p. 53); myth has become flesh, Cybele is alive again, and matrilineal civilization will be restored. Jocasta stands between two mythic orders, both of which are equally silly: they mystify flesh, confuse nature and culture and claim that remembering infantile experiences lies at the core of recognition.

This heady mixture of feminist utopian pulps and allusions to Sigmund Freud's writings about the Oedipus complex makes The Passion of New Eve simultaneously evoke and discard psychoanalysis as Carter enters her own "fort-da" game with it. She does the same to Jung's claim that myths "are original revelations of the preconscious psyche, involuntary statements about unconscious psychic happenings, and anything but allegories of physical processes" (Jung 1969, p. 154). One cannot forget 
psychoanalysis, and yet one cannot believe it is universally right and provides the key to human behaviour. Mother fails to craft a new mythology, and yet she succeeds to literally produce living symbols, mythic creatures whose bodies have the power to prompt déjà vu feelings. Her single-breasted Amazon-like priestesses have donated their breasts to allow her transformation into a god-head: she is breasted like a sow with two tiers of nipples, dark-skinned, obscenely naked and very tall with a false beard of crisp, black curls "like the false beard Queen Hatshepsut of the Two Kingdoms had worn" (Carter 1982, p. 59). Residing in "the deepest cave" (Carter 1982, p. 58) with dark, red walls she brings to the narrator anagnorisis: "She had been waiting for me all my life, I knew it the moment I saw her; but nothing in my life had hinted she might always have been there ... she was sacred" (Carter 1982, p. 58). Mother is human, but she is also a symbol which strangely resonates in the character's psyche. Recognition is evoked but at the same time reduced to a hazy déjà vu that signifies nothing. Carter plays with the Jungian idea that these myths resonate in our minds "collectively" and not because of our childhood or uterine experience. Yet, looking for the origin of the collective unconscious in some prehistoric epoch when humans inhabited the earth together with beasts and talked to the spirits is no less "shaky" than the anthropology of Frazer and Graves, who describe great goddesses. We only move further away in time, past matrilineal communities to stone-age hunter gatherers.

In Bound by Recognition, in the chapter significantly entitled "Tragic Recognition. Action and Identity in Antigone and Aristotle," Patchen Markell (2003) emphasizes the power of recognition to alter human fate. Referring to the story of Oedipus, the most famous example of a transformation from ignorance to knowledge, he opines: "So tightly intertwined are the satisfactions and dangers of anagnorisis that Jocasta's penultimate words to Oedipus-"May you never know who you are!"-seem to be meant at once as a curse and as a blessing" (Markell 2003, p. 62). In Angela Carter's fiction and non-fiction, the trope of recognition has a similarly dual nature: when skilfully evoked, it enriches the reading experience, and yet it should not be used to reinforce the myth of a universal human nature. The Jungian notion of myth as "revelation" is also a key concept in her works: myths reveal something about the psyche and in the psyche; as a result, intertextual allusions to myths are effective.

Reading Carter's fiction and non-fiction through a critical lens focused on myths, one can make several observations. Firstly, she is very much interested in the psychology of recognition and the theories of Aristotle and Jung help her to understand this mechanism. Secondly, Carter appreciates recognition in the books she reads and sees it as an invitation to an intertextual game. Yet, thirdly, her recognition should not be narrowed to a tool for "re-mythologizing," i.e., replacing the myths we have with a new set of politically correct ones. Carter expressed a number of times her distrust of feminist "Ur-religions" (Katsavos 1994, p. 1) by which she means myth-driven fantasies of primordial matriarchy, of utopian societies from before patriarchy that are ruled by happy and promiscuous women. Moreover, though one part of her oeuvre belongs in fiction and the other in cultural criticism, and though they do interact with each other and pass judgments on myths, Carter does not stop at commenting on continuing resonances of myth and traditional narrative. She also proffers her readers the delight of navigating nature and culture. Carter is first of all formidably well-read in myth theory and skilful at imitating specific discourses; she is a writer for whom theoretical premises reflect stereotypes in modern thinking. Keen on removing the camouflage from these epistemological traps, she is referred to as a great de-mythologizer and de-mystifier who strives for a re-negotiation of femininity and of sexual myths.

Funding: This research received no external funding.

Conflicts of Interest: The author declares no conflict of interest.

\section{References}

Aristotle. 1902. Poetic. Edited with Critical Notes and a Translation. Translated by S. H. Butcher. London: Macmillan. Barthes, Roland. 1993. Mythologies. Translated by Annette Lavers. London, Sydney, Auckland and Parktown: Vintage. 
Bristow, Joseph, and Trev Lynn Broughton, eds. 1997. The Infernal Desires of Angela Carter. London and New York: Longman.

Bryant, Sylvia. 1989. Re-Constructing Oedipus through "Beauty and the Beast". Criticism 31: 439-53. Available online: www.jstor.org/stable/23112304 (accessed on 20 June 2020).

Carter, Angela. 1982. The Passion of New Eve. London: Virago.

Carter, Angela. 1992. Nothing Sacred. London: Virago.

Carter, Angela. 1997. Shaking a Leg. London: Chatto and Windus.

Carter, Angela. 2012. Expletives Deleted: Selected Writings. New York: Random House.

Cassirer, Ernst. 1992. An Essay on Man: An Introduction to a Philosophy of Human Culture. London and New Haven: Yale University Press.

Cave, Terence. 2011. Recognitions: A Study in Poetics. Oxford: Oxford University Press. First published 1988.

Dimovitz, Scott A. 2016. Angela Carter. Surrealist, Psychoanalyst, Moral Philosopher. London and New York: Routledge.

Eliade, Mircea. 1968. Myth and Reality. Translated by Willard R. Trask. New York: Harvest Books.

Gamble, Sarah. 2006. Angela Carter. A Literary Life. London: Macmillan.

Gilbert, Sandra M., and Susan Gubar. 1984. The Mad Woman in the Attic. The Woman Writer and the Nineteenth-Century Literary Imagination. New Haven and London: Yale University Press.

Gordon, Edmund. 2016. The Invention of Angela Carter: A Biography. New York: Oxford University Press.

Gustar, Jennifer. 2004. Re-Membering Cassandra, or Oedipus Gets Hysterical: Contestatory Madness and Illuminating Magic in Angela Carter's "Nights at the Circus". Tulsa Studies in Women's Literature 23: 339-69. [CrossRef]

Jung, Carl Gustav. 1969. The Structure and Dynamics of the Psyche. Princeton: Princeton University Press.

Jung, Carl Gustav. 1978. Man and His Symbols. London: Picador.

Katsavos, Anna. 1994. A Conversation with Angela Carter by Anna Katsavos. The Review of Contemporary Fiction. Available online: https:/www.dalkeyarchive.com/a-conversation-with-angela-carter-by-anna-katsavos (accessed on 20 June 2020).

Markell, Patchen. 2003. Bound by Recognition. Princeton: Princeton University Press.

Mattson, Christina Phillips, and Maria Tatar. 2016. Fairy Tales, Myth, and Fantasy. In New Approaches to Teaching Folk and Fairy Tales. Edited by Christa C. Jones and Claudia Schwabe. Boulder: University Press of Colorado, pp. 21-34. Available online: www.jstor.org/stable/j.ctt1f2qr02.5 (accessed on 10 June 2020).

Neher, Andrew. 1996. Jung's Theory of Archetypes: A Critique. Journal of Humanistic Psychology 36: 61-91. [CrossRef]

Pérez-Gil, Maria Del Mar. 2007. The Alchemy of the Self in Angela Carter's “The Passion of New Eve". Studies in the Novel 39: 216-34. Available online: www.jstor.org/stable/20831916 (accessed on 20 June 2020).

Sage, Lorna. 1994. Introduction. In Flesh and the Mirror. Edited by Lorna Sage. London: Virago.

Segal, Robert A. 1999. Theorizing about Myth. Amherst: University of Massachusetts Press. 